\title{
Elevated erythrocyte phosphoribosylpyrophosphate and ATP concentrations in Japanese sumo wrestlers
}

\author{
BY Y. NISHIDA, I. AKAOKA, E. HAYASHI AND T. MIYAMOTO \\ Department of Medicine and Physical Therapy, Faculty of Medicine, University of Tokyo, \\ Bunkyo-ku, Tokyo, Japan 113
}

(Received 18 February 1982-Accepted 22 June 1982)

\begin{abstract}
1. Japanese sumo wrestlers have a diet rich in energy, which results in marked obesity. Their plasma urate and triglyceride levels were significantly elevated.

2. Erythrocyte phosphoribosylpyrophosphate (PRPP) and ATP concentrations in sumo wrestlers were significantly elevated when compared to the levels in control subjects.

3. There were no significant differences in erythrocyte PRPP synthetase (EC 2.7.6.1), purine nucleoside phosphorylase (EC 2.4.2.1) and hypoxanthine guanine phosphoribosyl transferase $(E C$ 2.4.2.8) activities between sumo wrestlers and control subjects.

4. Erythrocyte adenosine kinase $(E C 2.7,1.20)$, adenosine deaminase $(E C$ 3.5.4.4) and adenine phosphoribosyl transferase $(E C 2.4 .2 .7)$ activities in sumo wrestlers were significantly elevated.

5. It seems that sumo wrestlers have an increased turnover of adenine nucleotides which may contribute to hyperuricaemia.
\end{abstract}

Sumo is a national sport in Japan and there are approximately 800 professional sumo wrestlers. They enter the wrestlers' society at the age of 15 years and carry out hard training for $5 \mathrm{~h}$ daily. In the fighting match, overweight is a big advantage for the strong wrestler. Their high-energy diet is rich in protein and averages $23100 \mathrm{~J} / \mathrm{d}$ (396 g protein, $98 \mathrm{~g}$ fat, $780 \mathrm{~g}$ carbohydrate). Meals are taken twice daily and under these conditions their bodyweight increases significantly. The wrestlers show significantly elevated serum urate and triglyceride levels. Increased $24 \mathrm{~h}$ urinary urate excretions, mean value approximately $800 \mathrm{mg}$, were found in these subjects (Hayashi, 1971).

Many epidemiological and clinical studies have shown a strong correlation between body-weight and plasma urate levels (Rose \& Prior, 1963; Healey et al. 1966; O'Brien, et al. 1966; Prior et al. 1966; Hall et al. 1967). Reports have also shown that weight loss causes a fall in serum urate levels (Nicholls \& Scott, 1972; Emmerson 1973). However, the pathogenesis of hyperuricaemia caused by excess energy in the diet is still uncertain. The intracellular concentration of phosphoribosylpyrophosphate (PRPP) has been emphasized as an important factor in several routes of purine nucleotide synthesis (Fox \& Kelley, 1971). A rise in serum urate levels due to increased degradation of ATP is well established (Bode et al. 1973; Edwards et al. 1979).

In the present study, we measured erythrocyte PRPP and ATP concentrations in healthy male controls and sumo wrestlers. In experiments with chickens, Katunuma et al. (1970) reported increased activities of enzymes involved in purine metabolism, such as PRPP amidotransferase ( $E C$ 2.4.2.14), following increased protein intake. Therefore, enzymic activities related to purine metabolism in erythrocytes of sumo wrestlers and controls were also measured. The pathogenesis of hyperuricaemia in obese subjects is discussed.

\section{MATERIALS AND METHODS}

Blood samples were collected from sixty sumo wrestlers and from thirty healthy control subjects matched for age and sex. All blood specimens were collected on the same day by 
venepuncture into heparinized tubes after an overnight fast. Our study was performed as part of the health examination of the Japanese sumo wrestlers and was done during a resting period with no training. Blood samples were immediately centrifuged at $1900 \mathrm{~g}$ for $15 \mathrm{~min}$ at $4^{\circ}$ and erythrocytes were separated from the plasma. Erythrocytes were washed twice with 4 vols cold physiological saline $(9 \mathrm{~g}$ sodium chloride/1). The concentrations of PRPP and ATP, and the activity of adenosine deaminase (EC 3.5.4 .4; ADA) were estimated immediately. PRPP synthetase (EC 2.7.6.1), adenosine kinase (EC 2.7.1.20), purine nucleoside phosphorylase (EC 2.4.2.1; PNP), adenine phosphoribosyl transferase (EC 2.4.2.7; APRTase) and hypoxanthine guanine phosphoribosyl transferase (EC 2.4.2.8; HGPRTase) activities were measured in $7 \mathrm{~d}$ using packed cells stored at $-70^{\circ}$. Plasma was analysed for uric acid and triglycerides.

Erythrocyte PRPP concentrations were determined by the method of Henderson \& Khoo (1965) with minor modifications. Erythrocyte lysate $(25 \mu \mathrm{l})$ together with $275 \mu \mathrm{l} 50 \mathrm{~mm}$-Tris hydrochloric acid buffer ( $\mathrm{pH} 7 \cdot 4$ ) containing 1 mM-ethylene diamine tetra-acetic acid (EDTA), was heated at $100^{\circ}$ for $1 \mathrm{~min}$ and then chilled in an ice-cold water-bath. The tube was then centrifuged at $3000 \mathrm{~g}$ for $10 \mathrm{~min}$ at $4^{\circ}$. A portion of the supernatant fraction $(100 \mu \mathrm{l})$ was incubated for $30 \mathrm{~min}$ at $37^{\circ}$ in $100 \mu \mathrm{l} 100 \mathrm{~mm}$-Tris $\mathrm{HCl}$ buffer $(\mathrm{pH} 7 \cdot 4)$ containing $10 \mathrm{~mm}$-magnesium chloride, $100 \mu \mathrm{M}-\left[{ }^{14} \mathrm{C}\right]$ adenine $(10 \mu \mathrm{Ci} / \mu \mathrm{mol}$; Radiochemical Centre, Amersham, England) and $10 \mu$ highly purified APRTase solution. The reaction mixture $(25 \mu 1)$ was spotted onto thin-layer chromatography plates (Eastman Kodak, New York) and developed with butanol:methanol: water: ammonium hydroxide $(250 \mathrm{ml} / 1)$ $(60: 20: 20: 1$, by vol.). Purines were located on the chromatogram under u.v. light. AMP spots were scraped off, suspended in Aquasol II manufacturer's solution and radioactivity measured using a Packard Tri-Carb liquid-scintillation counter. APRTase was prepared from human erythrocytes by the method of Thomas $e t$ al. (1973). The specific activity of purified APRTase was $0.1 \mathrm{i}$.u./mg protein. Erythrocyte ATP concentrations were determined by the enzymic method described by Adam (1972) using an APT kit (Boehringer Mannheim Corp., Mannheim, West Germany).

Erythrocyte PRPP synthetase activity was determined by the method of Hershko et al. (1969) with minor modifications. Packed erythrocytes $(0.5 \mathrm{ml})$ were added to $3.0 \mathrm{ml}$ $1 \mathrm{~mm}$-EDTA and were dialysed in $8 \mathrm{~mm}$-sodium phosphate buffer, containing $1 \mathrm{~mm}$-EDTA and $5 \mathrm{~mm}$-glutathione, for $24 \mathrm{~h}$ at $4^{\circ}$. Dialysed erythrocytes $(50 \mu \mathrm{l})$ were incubated with $1.0 \mathrm{ml}$ of $100 \mathrm{~mm}$-Tris $\mathrm{HCl}$ buffer (pH 7.4) containing $0.35 \mathrm{~mm}$-ribose-5-phosphate, 0.5 mM-ATP, $1 \mathrm{~mm}$-EDTA, $25 \mathrm{~mm}$-reduced glutathione and $25 \mathrm{~mm}-\mathrm{MgCl}_{2}$. After $20 \mathrm{~min}$ incubation at $37^{\circ}$, the reaction mixtures was heated at $100^{\circ}$ for $1 \mathrm{~min}$ and then chilled in an ice-cold water-hath. Cold charcoal $(100 \mathrm{~g} / 1,0.25 \mathrm{ml})$ was added to the reaction mixture. The tube was centrifuged at $3000 \mathrm{~g}$ for $10 \mathrm{~min}$ at $4^{\circ}$. PRPP concentrations in $100 \mu \mathrm{l}$ of the supernatant fractions were measured by the method described previously.

HGPRTase activity was assayed by measuring the production of $\left[{ }^{14} \mathrm{C}\right] \mathrm{IMP}$ from $\left[{ }^{14} \mathrm{C}\right]$ hypoxanthine (Arnold et al. 1972). The assay mixture (total volume of $100 \mu \mathrm{l}$ ) contained $800 \mu \mathrm{M}-\left[{ }^{14} \mathrm{C}\right]$ hypoxanthine $(20.7 \mathrm{mCi} / \mathrm{mmol}$; Radiochemical Centre $), 2 \mathrm{~mm}$ PRPP and $10 \mathrm{~mm}-\mathrm{MgCl}_{2}$ in $55 \mathrm{~mm}$-Tris $\mathrm{HCl}$ buffer $(\mathrm{pH} \mathrm{7.4)}$. 7 he reaction was started by the addition of $50 \mu \mathrm{l}$ of the erythrocyte lysate to the assay mixture at $37^{\circ}$ for $30 \mathrm{~min}$ and terminated by the addition of $20 \mu \mathrm{l} 100 \mathrm{~mm}$-EDTA. A portion $(25 \mu \mathrm{l})$ was spotted onto thin-layer chromatography plates and developed as described previously. The radioactivity content of labelled IMP was measured as described for PRPP.

APRTase activity was assayed by measuring the production of $\left[{ }^{14} \mathrm{C}\right] \mathrm{AMP}$ from $\left[{ }^{14} \mathrm{C}\right]$ adenine. The reaction mixture containing $55 \mathrm{~mm}$-Tris $\mathrm{HCl}$ buffer $(\mathrm{pH} \mathrm{7.4),} 2 \mathrm{~mm}-\mathrm{PRPP}$, $10 \mathrm{mM}-\mathrm{MgCl}_{2}, 800 \mu \mathrm{M}-\left[{ }^{14} \mathrm{C}\right]$ adenine and $50 \mu \mathrm{l}$ haemolysate was incubated for $30 \mathrm{~min}$ at $37^{\circ}$. After the addition of $20 \mu \mathrm{l} 100 \mathrm{~mm}$-EDTA, $25 \mu \mathrm{l}$ of the reaction mixture was spotted on 
Table 1. Mean body-weight, plasma uric acid and plasma triglyceride levels, erythrocyte APT and erythrocyte phosphoribosylpyrophosphate (PRPP) concentrations and erythrocyte enzyme activities in sumo wrestlers and control subjects

(Mean values with their standard deviations)

\begin{tabular}{|c|c|c|c|c|}
\hline & \multicolumn{2}{|c|}{ Sumo wrestlers } & \multicolumn{2}{|c|}{ Control } \\
\hline & Mean & SD & Mean & SD \\
\hline \multicolumn{5}{|l|}{ Plasma (mg/l) } \\
\hline Uric acid & 54 & 16 & 46 & $8^{* *}$ \\
\hline Triglyceride & 1520 & 600 & 1170 & $300^{* *}$ \\
\hline \multicolumn{5}{|l|}{$\begin{array}{l}\text { Erythrocyte concentration } \\
\text { (nmol/ml packed cell) }\end{array}$} \\
\hline PRPP & $12 \cdot 2$ & $3 \cdot 2$ & 8.7 & $1 \cdot 6^{*}$ \\
\hline ATP & 1714 & 334 & 1224 & $214^{* *}$ \\
\hline \multicolumn{5}{|c|}{$\begin{array}{l}\text { Erythrocyte enzyme activity } \\
\text { (nmol/mg protein per } \mathrm{h} \text { ) }\end{array}$} \\
\hline PRPP synthetase & $34 \cdot 6$ & 4.9 & 35.4 & $5 \cdot 4$ \\
\hline $\begin{array}{l}\text { Purine nucleoside } \\
\text { phosphorylase }\end{array}$ & 1092 & 174 & 1062 & 192 \\
\hline HGPRTase & 118 & 18 & 121 & 23 \\
\hline Adenosine kinase & $12 \cdot 11$ & $2 \cdot 32$ & 6.93 & $2 \cdot 14^{* *}$ \\
\hline Adenosine deaminase & $25 \cdot 4$ & $6 \cdot 2$ & $19 \cdot 4$ & $7 \cdot 4 * *$ \\
\hline APRTase & $22 \cdot 6$ & $5 \cdot 2$ & 16.8 & $4 \cdot 0^{*}$ \\
\hline
\end{tabular}

$* P<0.05, \quad * * P<0.01$.

thin-layer chromatography plates and developed as described previously. The radioactivity in the labelled AMP was measured as described previously.

Adenosine kinase activity was measured by the method of Meyskens \& Williams (1970) with minor modifications. The reaction mixture containing $5 \mathrm{~mm}-\mathrm{ATP}, 10 \mathrm{mM}-\mathrm{MgCl}_{2}$, $200 \mu \mathrm{M}-\left[{ }^{14} \mathrm{C}\right]$ adenosine $(58 \mathrm{mCi} / \mathrm{mmol}$; Radiochemical Centre), coformycin $(1 \mu \mathrm{g} / \mathrm{ml})$ (Meiji Seika Corp., Tokyo) in $50 \mathrm{~mm}$-acetate buffer ( $\mathrm{pH} \mathrm{5.7)} \mathrm{and} \mathrm{haemolysates} \mathrm{were}$ incubated for $20 \mathrm{~min}$ at $37^{\circ}$. The reaction was terminated by the addition of $20 \mu 1$ $100 \mathrm{~mm}$-EDTA. Portions of the reaction mixture $(25 \mu \mathrm{l})$ were applied to thin-layer plates and developed as described for AMP.

Erythrocyte ADA activity was measured by the method of Hopkinson et al. (1969). The assay mixture contained $1 \mathrm{~mm}$-adenosine, 0.025 i.u. PNP (Boehringer Mannheim Corp.) and $20 \mu \mathrm{l}$ xanthine oxidase ( $8 \mathrm{i} . \mathrm{u} . / \mathrm{ml}$; PL Biochemicals, Milwaukee, Wisconsin) in $3.0 \mathrm{ml}$ $0.05 \mathrm{M}$-phosphate buffer ( $\mathrm{pH} 7.4$ ). After addition of $100 \mu 11: 10$ diluted erythrocyte lysate, the increase in absorbance at $292.5 \mathrm{~nm}$ was recorded. On determining the erythrocyte PNP

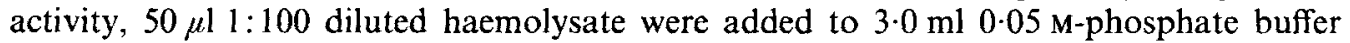
(pH 7.4) containing $1 \mathrm{~mm}$-inosine and $20 \mu \mathrm{l}$ xanthine oxidase. The increase in absorbance at $292.5 \mathrm{~nm}$ was recorded.

Uric acid was measured by the enzymic methods of Liddle et al. (1959), triglyceride by the method of Sugiura et al. (1977) and protein content by the method of Lowry et al. (1951). Statistical analysis was performed using the $F$-test. 


\section{RESULTS}

As shown in Table 1, the mean body-weight of sumo wrestlers was elevated significantly compared to those of controls. There was a significant difference between the mean $( \pm S D)$ values of plasma triglyceride of sumo wrestlers and controls. The mean plasma urate of sixty sumo wrestlers was significantly higher than the average level of the matched controls $(P<0.01)$. Hyperuricaemia defined as a plasma urate concentration in excess of $70 \mathrm{mg} / 1$ was present in $15 \%$ of wrestlers and in none of the controls. In wrestlers, body-weight had a significant positive correlation with plasma urate level $(r 0.509)$. The mean erythrocyte PRPP content of sumo wrestlers was significantly higher than the mean content of the controls $(P<0.05)$. However, there was no significant relationship between erythrocyte PRPP concentration and plasma urate level in sumo wrestlers $(r 0 \cdot 151)$. Mean erythrocyte ATP concentration in sumo wrestlers was significantly higher than that of controls $(P<0.01)$.

The results of enzymic activities in erythrocytes are shown in Table 1 . There were no significant differences in mean erythrocyte PRPP synthetase, PNP and HGPRTase activities between sumo wrestlers and controls. However, the mean adenosine kinase, ADA and APRTase activities in the sumo wrestlers were significantly higher than those of controls.

\section{DISCUSSION}

In the present study, Japanese sumo wrestlers showed significantly increased body-weight and elevated serum urate and triglyceride levels. In addition, a significant positive correlation between body-weight and plasma urate level was observed in sumo wrestlers. These results are in agreement with previous findings of Healey et al. (1966).

However, the pathogenesis of hyperuricaemia in obese subjects remains uncertain. Accelerated purine biosynthesis or impaired renal handling of uric acid or both are known to be involved in hyperuricaemia. In chicks, administration of a high-protein diet resulted in increased urate excretion (Itoh \& Tsushima 1972; Hevia \& Clifford, 1977). Increased urinary urate excretion after a high-protein intake in humans was also reported by Bowering et al. (1970). However, Emmerson (1973) showed that weight loss in an obese gouty patient caused a rise in the renal urate clearance and a slight reduction in the rate of urate production. After weight loss on a low-energy diet, a fall in plasma urate levels was observed by Nicholls \& Scott (1972) and urinary uric acid decreased after weight loss only in subjects with the highest initial urinary urate levels. These findings suggested that obese subjects have decreased renal urate clearance. In the present study, the PRPP concentrations in erythrocytes of sumo wrestlers were significantly elevated when compared with controls. However, there was no significant positive correlation between erythrocyte PRPP concentration and plasma urate in the sumo wrestler. It seems that many factors contribute to hyperuricaemia in obese subjects.

In animal experiments, such as with chicks and rats, there were increased activities of enzymes involved in purine metabolism following increased protein administration. Arnold et al. (1972) found that dietary purine restriction increases HGPRTase activity in erythrocytes of patients with Lesch-Nyhan syndrome. Contrary to expectations, there were no significant differences in erythrocyte PRPP synthetase, PNP and HGPRTase activities between sumo wrestlers and control subjects. However, significantly increased activities of adenosine kinase, ADA and APRTase were found in erythrocytes of sumo wrestlers. In addition, erythrocyte ATP concentrations were also significantly elevated in sumo wrestlers. A rise in serum urate levels due to increased degradation of ATP is well established (Bode et al. 1973; Edwards et al. 1979). These results suggest that both increased formation and 
turnover of adenine nucleotides in sumo wrestlers may exist and may induce production of uric acid, leading to hyperuricaemia.

The possibility of increased purine nucleotide degradation in obese subjects and induction of enzymes such as APRTase by high protein intake warrants further study.

\section{REFEREN CES}

Adam, L. (1972). In Methods in Enzymatic Analysis, P. 539 [H. V. Bergmeyer, editor]. Berlin: Weinhein Verlag Chemie.

Arnold, W. J. \& Kelley, W. N. (1973). J. clin. Invest. 52, 970.

Arnold, W. J., Meade, J. C. \& Kelley, W. N. (1972). J. clin Invest. 51, 1805.

Bode, J. Ch., Zelder, O., Rumpelt, H. J. \& Wittkamp, U. (1973). Eur. J. clin. Invest. 3, 436.

Bowering, J., Calloway, D. H., Margen, S. \& Kaufmann, N. A. (1970). J. Nutr. 100, 249.

Edwards, N. L., Recker, D. \& Fox, I. H. (1979). J. clin. Invest. 63, 922.

Emmerson, B. T. (1973). Aust. N.Z. Jl Med. 3, 410.

Fox, I. H. \& Kelley, W. N. (1971). Anns int Med. 74, 424.

Hall, A. P., Barry, P. E., Dawber, T. R. \& McNamara, P. M. (1967). Amer. J. Med. 42, 27.

Hayashi, E. (1971). Ryumachi 11, 11.

Healey, L. A., Cancer, J. E. Z., Bassett, D. R. \& Decker, J. L. (1966). J. Am. med. Ass. 196, 152.

Henderson, J. F. \& Khoo, M. K. Y. (1965). J. biol. Chem. 240, 2349.

Hershko, A., Razin, A. \& Mager, J. (1969). Biochim. biophys. Acta 184, 64.

Hevia, P. \& Clifford, A. J. (1977). J. Nutr, 107, 969.

Hopkinson, D. A., Cook, P. J. L. \& Harris, H. (1969). Ann. Hum. Genet. 32, 361.

Itoh, R. \& Tsushima, K. (1972). Biochim. Biophys. Acta. 273, 229.

Katunuma, N., Matsuda, Y. \& Kuroda, Y. (1970). Adv. Enzyme Regul. 8, 73.

Liddle, L., Seegmiller, J. E. \& Laster, L. (1959). J. Lab. clin. Med. 54, 903.

Lowry, O. H., Rosebrough, N. J., Farr, A. L. \& Randall, R. J. (1951). J. biol. Chem. 193. 265.

Meyskens, F. L. \& Williams, H. (1970). Biochim. biophys. Acta 240, 170.

Nicholls, A. \& Scott, J. T. (1972). Lancet ii, 1223.

O'Brien, W. M., Burch, T. A. \& Bunim, J. J. (1966). Ann. rheum. Dis. 25, 117.

Prior, I. A. M., Rose, B. S., Harvey, H. P. B. \& Davidson, F. (1966). Lancet i, 333.

Rose, B. S. \& Prior, I. A. M. (1963). Ann rheum. dis. 22, 410.

Sugiura, M., Oikawa, T., Hirano, K., Maeda, H., Yoshimura, H., Sugiyama, M. \& Kuratsu, T. (1977). Clinica chim. Acta 81, 125.

Thomas, C. B., Arnold, W. J. \& Kelley, W. N. (1973). J. biol. Chem. 248, 2529. 